\title{
1. Collaboration in public service delivery: what, when and how
}

\section{Anka Kekez, Michael Howlett and M Ramesh}

\section{COLLABORATIVE SERVICE DELIVERY IN THEORY AND PRACTICE}

The growing complexity of collective problems and social needs, aligned with pressures for cheaper and better public services, have induced efforts at policy reform in many developed and developing countries over the past several decades. Many of these efforts have featured restructuring of old or creation of new arrangements for the implementation of public policies and the provision of public services (Osborne 2010). This volume thus aims to bring both more clarity into the conceptualization of different arrangements for collaboration in service delivery and to advance the understanding of the conditions that are critical for their success and of pathways through which they might unfold.

Initially, the sentiment behind many of these reform efforts of the 1980s and 1990s favoured separation of policy design and implementation with the latter activity to be, wherever possible, transferred away from government agencies viewed as inherently inefficient and, in many countries, often corrupt. The subsequent externalization of government-led service delivery in this era was not so much towards the third sector or non-profit organizations but towards private for-profit actors in a process of 'marketization'. In recent years, however, poor experiences with many privatizations and contracting-out provisions have shifted this preference away from market-based modes of service delivery towards more network-oriented implementation through various forms of collaborative partnerships (Alford and O'Flynn 2012; Howlett and Ramesh 2016).

These efforts have sought to create new arrangements, in many cases reversing earlier efforts of policy disaggregation from the market-based era, but also addressing both new and old areas in which anticipated gains in efficiency, effectiveness and legitimacy from enhanced collaboration with the 'third' (non-profit) and 'fourth' (family and volunteer) sectors (Ansell, Sørensen and Torfing 2017). 
These movements have led to, and been accompanied by, developments in contemporary theory and practice of policy implementation and service delivery which extend far beyond the zero-sum notions of state-market relations which were a feature of earlier eras and involve a focus on collectively defined outcomes whose achievement relies on synergy between different agencies and levels of government, as well as between public, private and civic actors (Osborne 2010; Hill and Hupe 2014). Collaboration in service delivery mixes, it is often claimed, induces the best of government-, market- and civil society-based arrangements by bringing together key governmental and non-governmental actors in a constructive and inexpensive way (Rhodes 1997; Koffijberg, De Bruijn and Priemus 2012).

As a result of these developments both in theory and on-the-ground practice, contemporary governance now exists as a complex medley of either or both hierarchical approaches - regulatory relationships, bureaucratic oversight and service delivery - as well as market- and network-based non-hierarchical approaches such as relational contracting, collaborative partnerships and increasingly co-production (Bovaird 2006; Brandsen and Hout 2006; Pestoff 2006; Van Slyke 2009; Alford and O'Flynn 2012). Provision of many welfare, education, health and other services now features many techniques and instruments related to these modes of collaboration, often juxtaposed or superimposed on each top of each other.

Lost in the development of these alternative modes of collaborative service delivery by governments around the world in a variety of sectors, however, has been the understanding of exactly (a) in what instances a particular implementation arrangement can be considered as 'collaborative' and (b) when and how such arrangements are able to address specific social needs or particular sector's problem, either singly or conjointly.

The conceptual and taxonomical confusion which plagues many accounts of collaboration in which otherwise dissimilar efforts for enhanced effectiveness of public services are often clumped under the same rubric, ignores their nuances and differences. Moreover, although often promoted as solutions to a wide variety of policy and governance challenges, many preferences for specific types of collaboration have little evidence supporting their deployment (see Kjær 2004; Van Kersbergen and Van Waarden 2004; Adger and Jordan 2009; Howlett, Rayner and Tollefson 2009; Hysing 2009; Tunzelmann 2010).

The use, and abuse, of collaborative implementation mixes thus requires better analysis and it is the aim of this book to help bring these activities into sharper focus. In doing so, as presented in Table 1.1, the book will focus on six major arrangements in public policy implementation and service delivery which may be based on or augmented by collaboration and assess both their capabilities and constraints, as well as their preconditions in terms of social arrangements and state and societal capacities and capabilities. These six 
alternative arrangements for collaborative public service delivery include: (1) consultation - in which goods and services continue to be provided by state agencies but with enhanced participation and dialogue throughout this process by stakeholders, clients and the public; (2) contracting-out - the classic mode of marketization from the 1980s and 1990s in which goods and service delivery costs are borne by the state but implementation is undertaken by private, for-profit actors and businesses; (3) commissioning - similar to contracting out but in which governmental organizations strategically engage in outcome-oriented acquisition of public services which may be provided by for-profit, civil society or public organizations; (4) co-management - in which public services are produced by the civil society organizations, while the management of these services and decisions on a wide variety of issues surrounding how delivery occurs and who benefits from it, is done collectively by the public and civil society and business actors that can be involved in delivery; (5) co-production - in which the actual delivery of goods and services is undertaken jointly by the actors involved in individual transactions, from clients to producers; and (6) certification - in which third party certifiers rather than government regulators or private or non-profit managers determine standards for goods and service delivery and monitor and enforce, however loosely, production, distribution and consumption activities.

These are all modes of governance related to policy implementation and are the focus of this book. Other forms of collaboration exist, of course, as along with arrangements set out in Table 1.1, governments and their agencies can also collaborate with non-governmental actors through arrangements referred in the literature by terms such as co-construction, co-planning, co-governance and alike. Unlike the six relationships and activities cited above, however, these are primarily applied in the formulation or evaluative stages of policy cycle and are not discussed here, except in passing (Brandsen and Pestoff 2006; Verschuere, Brandsen and Pestoff 2012).

\section{WHAT ARE COLLABORATIVE ARRANGEMENTS: UTILIZING A GOVERNANCE LENS}

Collaborative implementation arrangements such as consultative in-house service delivery, contracting-out, commissioning, co-management, co-production and certification represent alternative arrangements through which collaboration can be introduced directly in policy implementation and public service delivery (Kekez, Howlett and Ramesh 2018). In much of the literature on these subjects, each is discussed as a separate activity but also an example of a more general category of 'new' collaborative governance modes which involve different levels of collaboration and interaction between participants in the implementation process (Weir 2010; Nohrstedt 2016). 
Table $1.1 \quad$ Alternative arrangements in public service delivery: definitions and sources

\begin{tabular}{|c|c|c|}
\hline Arrangement & Basic definition & Some key sources \\
\hline $\begin{array}{l}\text { Consultative } \\
\text { in-house delivery }\end{array}$ & $\begin{array}{l}\text { Direct provision of services by the public sector } \\
\text { organizations and their employees but enhanced } \\
\text { via consultations and dialog with users and their } \\
\text { associations. }\end{array}$ & $\begin{array}{l}\text { Fung and Wright 2003; Fung } \\
\text { 2006; Johnson } 2015 .\end{array}$ \\
\hline Contracting-out & $\begin{array}{l}\text { Reduction of state involvement in the provision } \\
\text { of public services, through the replacement of } \\
\text { civil servants and internal procurement processes } \\
\text { with contractual arrangements with, usually, } \\
\text { non-governmental organizations, primarily } \\
\text { businesses. }\end{array}$ & $\begin{array}{l}\text { Ascher 1987; English and } \\
\text { Skellern 2005; Roehrich, Lewis } \\
\text { and George 2014; Vincent-Jones } \\
\text { 2006; Vining, Boardman and } \\
\text { Poschmann 2005. }\end{array}$ \\
\hline Commissioning & $\begin{array}{l}\text { Public services are designed and delivered by } \\
\text { business, civil society or public actors competing } \\
\text { in an open market while government agencies } \\
\text { ensure strategic alignment of commissioned } \\
\text { actions with clients' expectations and desired } \\
\text { policy outcomes. }\end{array}$ & $\begin{array}{l}\text { Bovaird and Davies 2011; } \\
\text { Bovaird, Dickinson and Allen } \\
\text { 2012; Bovaird, Briggs and Willis } \\
\text { 2014; Dickinson 2014; Rees } \\
\text { 2014; Sturgess 2018. }\end{array}$ \\
\hline Co-management & $\begin{array}{l}\text { Civil society organizations are responsible for } \\
\text { production of public services which they produce } \\
\text { in partnership with governmental and business } \\
\text { organizations. }\end{array}$ & $\begin{array}{l}\text { Brandsen and Hout 2006; } \\
\text { Brandsen and Pestoff 2006; } \\
\text { Brinkerhoff 2002; Carlsson and } \\
\text { Berkes 2005, Pestoff, Brandsen } \\
\text { and Verschuere 2012; Steurer } \\
2013 .\end{array}$ \\
\hline Co-production & $\begin{array}{l}\text { In the interaction with employees of organizations } \\
\text { that provide services, citizens actively contribute } \\
\text { to service they personally receive. }\end{array}$ & $\begin{array}{l}\text { Alford 2009; Bovaird and } \\
\text { Loeffler 2012; Brandsen and } \\
\text { Honingh 2016; Brandsen and } \\
\text { Pestoff 2006; Parks et al. 1981; } \\
\text { Pestoff 2006; Pestoff, Brandsen } \\
\text { and Verschuere 2012; Voorberg, } \\
\text { Bekkers and Tummers 2015. }\end{array}$ \\
\hline $\begin{array}{l}\text { Third party } \\
\text { certification }\end{array}$ & $\begin{array}{l}\text { Civil society groups and firms (typically in } \\
\text { sectors such as forestry, fisheries and agriculture) } \\
\text { contribute to quality control by determining } \\
\text { standards for goods and service delivery and } \\
\text { by monitoring production, distribution and } \\
\text { consumption activities. }\end{array}$ & $\begin{array}{l}\text { Cashore 2002; Cashore, Auld and } \\
\text { Newsom 2004; Cutler, Haufler } \\
\text { and Porter 1999; Gulbrandson } \\
\text { 2014; Vince and Haward } 2017 .\end{array}$ \\
\hline
\end{tabular}

Source: Adapted from Kekez, Howlett and Ramesh (2018: 244). 
Unfortunately, these literatures exist largely independently of each other in fields such as public management, public administration, implementation and policy studies and very often one of these 'sub-categories' is viewed as being synonymous with the general category itself rather than as a specific type (Wyborn 2015). This is not helpful and is a problem this volume addresses by bringing together these disparate literatures into coherent discussions of each tool within the more general category of collaborative governance writ large. That is, progress on better understanding of comparative strengths or weaknesses among different forms of collaboration can occur only once the general category is properly defined and the nature of each of the six types of arrangements set out above is made clearer in terms of a general model of governance modes.

In its broadest sense, 'governance' is a term used to describe the mode of coordination exercised by governmental actors over social ones in their efforts to solve familiar problems of collective action inherent to government and governing (Kooiman 1993, 2000; de Bruijn and ten Heuvelhof 1995; Majone 1997; Rhodes 1997; Klijn and Koppenjan 2000b). Collaborative service delivery, in its core, 'is a specific mode of governance by which policies are implemented and services are delivered through interaction between two or more of state, market and civil society actors' (Kekez, Howlett and Ramesh 2018: 245). As Steurer (2013) suggested, in the design and implementation of public policies, these three basic governance actors can be portrayed as interacting within a set of inter-related spheres of activity generating at least four ideal typical governance arrangements at their intersections: market governance between governments and business, civil society governance between governments and non-governmental actors, private governance between market and civil society actors, and network governance between all three.

However, this logic of governance types is more extensive than Steurer suggests since within each combination different sets of actors can have different core roles and strengths. When variations on the strength of each actor in a governance relationship is included - that is, which actor is dominant in the relationship - the types of governance arrangements or 'modes' stretch to at least a dozen, as shown in Figure 1.1.

Figure 1.1 shows that mechanisms involving the dominance of hierarchy (cells 1 and 2) essentially make for a strong and weak mode of civil society governance while those featured by the dominance of market mechanisms (cells 3 and 4) form strong and weak modes of market governance. Trilateral arrangements in which hierarchy dominates (cells 5 and 6), strongly or weakly, can be described as corporatist modes of governance while trilateral mechanisms in which network or market dominates and the government plays a secondary role (cells 7, 8, 9 and 10) constitute different forms of private sector or 
NGO-led network governance. Finally, private mode of governance can also involve market and network mechanisms (cells 11 and 12).

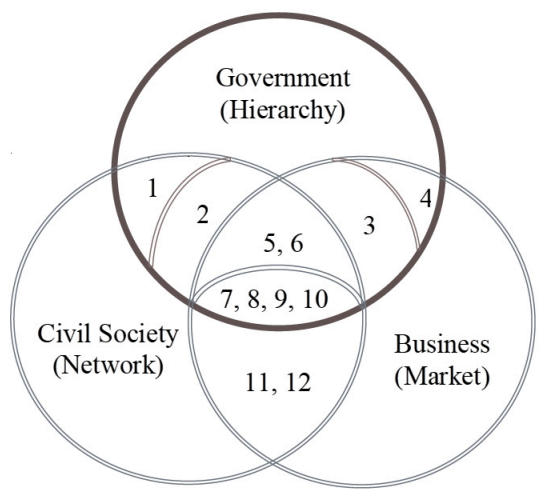

\begin{tabular}{|c|c|c|}
\hline Cell \# & $\begin{array}{l}\text { Governance Mechanisms, } \\
\text { by importance }\end{array}$ & Mode of Governance \\
\hline 1 & Hierarchy - Network & Weak Civil Society Governance \\
\hline 2. & Network - Hierarchy & Strong Civil Society Governance \\
\hline 3 & Market - Hierarchy & Strong Market Governance \\
\hline 4 & Hierarchy - Market & Weak Market Governance \\
\hline 5. & Hierarchy-Market - Network & State Corporatist Governance \\
\hline 6. & Hierarchy - Network - Market & Societal Corporatist Governance \\
\hline 7. & Network-Market - Hierarchy & \multirow{4}{*}{$\begin{array}{l}\text { Various forms of private sector } \\
\text { and civil society led Network Governance }\end{array}$} \\
\hline 8. & Network - Hierarchy - Market & \\
\hline 9. & Market - Network - Hierarchy & \\
\hline 10. & Market - Hierarchy - Network & \\
\hline 11. & Market - Network & Strong Private Governance \\
\hline 12. & Network-Market & Weak Private Governance \\
\hline
\end{tabular}

Source: Adapted from Howlett and Ramesh (2016: 303).

Figure 1.1 Modes of governance, including variation by lead actor

From this perspective all six of the collaborative modes of activity listed in Table 1.1 can be seen to be different kinds of hybrid governance arrangements involving specific combinations of actors with specific roles and strengths (see Figure 1.2).

Figure 1.2 illustrates that while there are 12 broad modes of governance involving some type of cross-sectoral interaction, each of six collaborative arrangements for service delivery exists at the nexus of these categories and features different types of government, business and civil society relations 


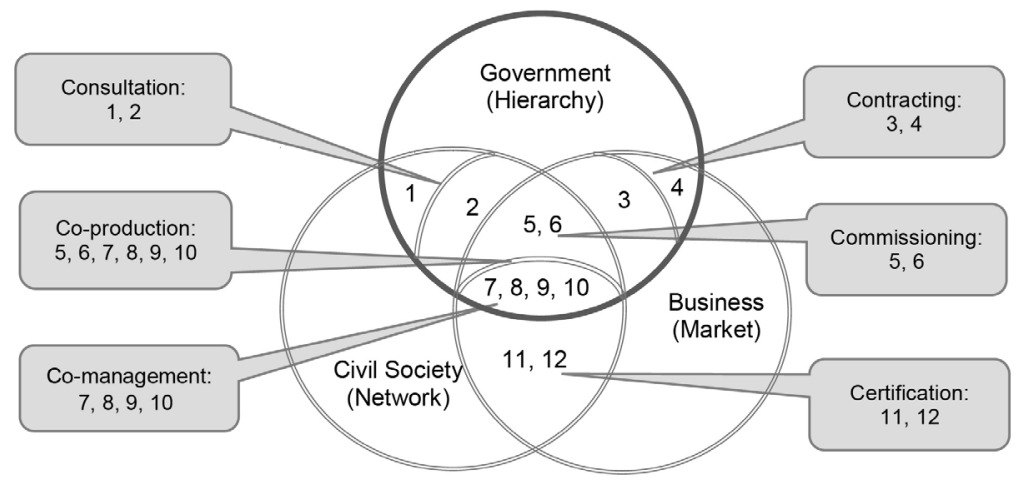

Figure 1.2 Consulting, contracting-out, commissioning, co-management, co-production and certification as hybrid governance modes

(Kekez, Howlett and Ramesh 2018). Thus, cells 1 and 2 involve government and civil society, with either one or the other being dominant in the arrangement in which in-house production of public services is often enhanced with consultations with users and their associations. Correspondingly, cells 3 and 4 often involve the contracting-out mode of service delivery in relationships that can be characterized by dominance of either the market or government. Networks or markets are dominant in the certification mode found in cells 11 and 12, while cells 5-10 describe commissioning, co-management and co-production relationships, all of which are variations on service delivery mechanisms involving hierarchy, markets and networks. Using this lens thus provides a clear distinction, for example, between commissioning and co-management. While in the case of the former, government maintains its status as the leading actor, in the case of the latter it delegates it to civil society organizations. On the other hand, co-production can function with different dominating actors and tends to overlap with commissioning and co-management, which explains the confusion often present in the literature and in case studies about what are these arrangements and how they function.

This is a broader perspective on collaborative governance than that commonly found in the literature in which collaboration is limited to those policy design and implementation arrangements between state and non-state actors in which participants engage 'in a collective decision-making process that is formal, consensus oriented and deliberative' (Ansell and Gash 2008: 544). In addition to regarding more types of governance relationships as collaborative 
ones, it also highlights that cross-sectoral interaction in policy implementation and public service delivery might involve different degrees of collaboration (Bryson, Crosby and Stone 2006; Emerson, Nabatchi and Balogh 2012).

Certification, for example, as a form of partnership involving primarily non-state actors, does not fully fit into a model of collaborative governance arrangements if the definition of collaboration involves the initiation or instigation of these relationships by public agencies. Nevertheless, these relationships between the business and civil society organizations involved in third party certification are essentially collaborative, in the sense that both types of actors are interdependently yet autonomously engaged in a joint creation of norms, 'rules and structures governing their relationships and ways to act or decide on the issues that brought them together' (Thomson, Perry and Miller 2007: 25, see also Cashore 2002, Vince and Haward 2017).

The governance lens adopted here also suggests that even though the engagement of non-governmental organizations and citizens in the co-management, commissioning and co-production of public service in practice might end up with competition, asymmetric dependence or even co-option, all three types of trilateral arrangements are ideal-typically based on collaboration (Brandsen and Hout 2006; Milbourne 2009; Pestoff 2009; Henfrey and Penha-Lopes 2018). In their most intensive and advocated forms, co-management, commissioning and co-production are, thus, characterized by negotiative interaction and joint contribution of multiple stakeholders to provision of public services and their outcomes (Bovaird 2007; Pestoff and Brandsen 2010; Alford and O'Flynn 2012; Rees 2014; Bovaird and Loeffler 2016).

It also shows how in arrangements most closely aligned with civil society or market regimes, collaboration does not necessarily represent a dominating or ideal-typical feature, but can function more as a value added dimension. Consultative efforts, for example, thus can operate in a largely tokenistic manner, but can also be strengthened through collaborative interaction with citizens and their associations in which citizen priorities are in fact injected in the design and delivery of public services (Johnson 2009). Similarly the effectiveness of contracting-out is often enhanced through participation of multiple actors in negotiations over not just operational and price details but also over basic service design issues. Moreover, even though this arrangement primarily functions in typical principal-agent settings, it may also involve ownership-sharing and partnerships between public and private actors (Entwistle and Martin 2005; Alford and O'Flynn 2012) which introduce additional collaborative dimensions. 


\section{COLLABORATIVE ARRANGEMENTS IN SERVICE DELIVERY: WHEN AND HOW THEY SUCCEED AND WHY THEY OFTEN FAIL}

On a more general level, this analysis suggests that in instances in which it functions as a dominating feature of implementation arrangements and, perhaps even more, in instances in which it serves as a supplemental dimension, collaboration involves hybridized public service delivery whose success or failure involves more complex issues around capacity requirements and pre-conditions than is typically found in the literature on the subject $(\mathrm{Wu}$, Ramesh and Howlett 2015).

In order to shed light on conditions and pathways conducive for the success of different modes of collaboration in public service delivery, this volume adopts and extends the model of capacity challenges developed by Howlett and Ramesh $(2014,2016)$ which highlights critical gaps in the analytical, managerial, and political competences - 'Achilles Heels' - of governing actors in different governance arrangements.

In this model analytical capacity is required in order to allow effective generation and assessment of policy alternatives and application of governing techniques with a higher likelihood of success. Managerial capacity affects the effective deployment of both state and societal resources for the achievement of policy objectives, while political capacity refers to the need for any such relationships to ensure continuing support for effective policy design and execution regardless of how it is actually conducted.

The utilization of each type of capacity, however, is highly dependent on the availability of resources or capabilities that exist at the different levels of political-societal relations. Resources available at the individual level thus involve capabilities that enable executive politicians, public managers, street level workers and users to engage as individuals in the design, delivery and evaluation of public policies (Colebatch 2006; Colebatch, Hoppe and Noordegraaf 2010; Howlett and Walker 2012). Resources that exist at the organizational level relate to characteristics of (inter)organizational relations and structure or make up of policy-relevant organizations, which circumscribe their members' capabilities to carry on their policy- or governance-related tasks (Tiernan and Wanna 2006; Gleeson et al. 2011). Finally, at the level of system, crucial are support and trust that a public agency or its non-governmental partners enjoy from political leaders and from the society at large (Blind 2006). Such factors are determinants of organizational capabilities and, consequently, of policy actors' capability to perform their policy functions (Howlett and Ramesh 2014, 2016). 
These three types of competences or skills are crucial for the success of policy and governance-related activities (Tiernan and Wanna 2006; Gleeson, Legge and O'Neill 2009; Wu et al. 2010; Gleeson et al. 2011; Fukuyama 2013; Rotberg 2014) but may or may not exist in any specific implementation circumstance. The volume's central argument is that, like other more well-known 'pure' governance modes (Howlett and Ramesh 2014, 2016), each of the six service delivery arrangements set out above requires some quantum of all three types of capacity at all three locations of resources or capabilities if it is to be high functioning and match its theoretical potential.

In general, collaborative service delivery arrangements require, at minimum, at the individual level, political competences that extend beyond officials' leadership skills and involve their good judgment about when and how to invite non-governmental actors in the service delivery process (Kekez, Howlett and Ramesh 2018). Such judgments, at the level of organizations, need to be followed up with the political designation of conditions that will frame the joint action towards policy outcomes and with the empowerment of public managers for the facilitation of collaborative interaction. At the larger level, government's ability to ensure legitimacy and trust in its action on the part of stakeholders and citizens in general is a critical component of all modes of collaboration's operation and results (Edelenbos and van Meerkerk 2016a; Papadopoulos 2016; Sørensen and Torfing 2016a; Kekez, Howlett and Ramesh 2018).

In other words, 'collaborative arrangements can only be effective if government is able to create meaningful opportunities for interaction and mobilize different actors to invest energy, resources and knowledge in collaborative production of public services' (Kekez, Howlett and Ramesh 2018: 247). While most on-the-ground modes do not always attain their highest potential, the success of collaborative arrangements is highly dependent on these political competences which enable governments to mobilize and maneuver the meaningful contribution of non-governmental actors into the implementation process in any of the six ways cited above.

This is a general need. However, while the success of all collaborative modes of service delivery is linked to political capacities, each collaborative arrangement has a need for a certain critical analytical or managerial capability which serves as its own 'Achilles Heel' (Kekez, Howlett and Ramesh 2018). That is, as set out in Table 1.2, they each have the need for at least one specific capacity which, if missing, means they are unlikely to function as intended and will generate policy failures rather than the successes wished upon them.

That is, in the consultation mode, collaboration will only be effective if knowledge systems exist allowing relevant inputs to be made into government regulatory and service production activities. Whereas in co-production, for example, as a mode of service delivery in which collaboration is primarily 
Table 1.2 Modes of collaboration on the dimensions and levels of policy and governance capacity

\begin{tabular}{|c|c|c|c|}
\hline $\begin{array}{l}\text { Resource Level } \\
\text { Skill Dimension }\end{array}$ & $\begin{array}{l}\text { Individual } \\
\text { Capabilities }\end{array}$ & $\begin{array}{l}\text { Organizational } \\
\text { Capabilities }\end{array}$ & $\begin{array}{l}\text { System } \\
\text { Capabilities }\end{array}$ \\
\hline $\begin{array}{l}\text { Analytical } \\
\text { Competences }\end{array}$ & $\begin{array}{l}\text { Policy Analytical Capacity } \\
\text { CONTRACTING-OUT } \\
\text { Domain knowledge and } \\
\text { analytical skills as a base } \\
\text { for effective negotiation } \\
\text { and administration of } \\
\text { contracts. }\end{array}$ & $\begin{array}{l}\text { Organizational Information } \\
\text { Capacities } \\
\text { COMMISSIONING } \\
\text { Appropriate alignment of } \\
\text { budget and other policy } \\
\text { inputs with outputs and } \\
\text { outcomes. }\end{array}$ & $\begin{array}{l}\text { Knowledge System } \\
\text { Capacity } \\
\text { CONSULTATION } \\
\text { Institutions and } \\
\text { opportunities for } \\
\text { knowledge generation, } \\
\text { mobilization and use. }\end{array}$ \\
\hline $\begin{array}{l}\text { Managerial } \\
\text { Competences }\end{array}$ & $\begin{array}{l}\text { Managerial Expertise } \\
\text { Capacity } \\
\text { CO-PRODUCTION } \\
\text { Motivation and ability } \\
\text { of service providers } \\
\text { to engage in creation } \\
\text { of knowledge and } \\
\text { quality together with } \\
\text { citizens, networks and } \\
\text { communities. }\end{array}$ & $\begin{array}{l}\text { Administrative Resource } \\
\text { Capacity } \\
\text { CO-MANAGEMENT } \\
\text { Management of } \\
\text { partnerships embedded } \\
\text { in the trust, social capital } \\
\text { and reciprocity between } \\
\text { involved organizations. }\end{array}$ & $\begin{array}{l}\text { Accountability and } \\
\text { Responsibility System } \\
\text { Capacity } \\
\text { CERTIFICATION } \\
\text { State regulation and } \\
\text { transparent adjudicative } \\
\text { system ensuring that } \\
\text { trust and system-level } \\
\text { legitimacy of third party } \\
\text { certifiers is maintained. }\end{array}$ \\
\hline Political & \multicolumn{3}{|c|}{ Required by all service delivery arrangements involving collaboration } \\
\hline Competences & $\begin{array}{l}\text { Political Acumen Capacity } \\
\text { Judgment about when } \\
\text { and how to bring in the } \\
\text { interactivity in the service } \\
\text { delivery process. }\end{array}$ & $\begin{array}{l}\text { Organizational Political } \\
\text { Capacity } \\
\text { Framing conditions and } \\
\text { milestones for joint action } \\
\text { and empowering public } \\
\text { managers to facilitate } \\
\text { collaboration. }\end{array}$ & $\begin{array}{l}\text { Political-Economic System } \\
\text { Capacity } \\
\text { Government enjoys trust } \\
\text { from the society in large } \\
\text { and is able to mobilize } \\
\text { actors and resources. }\end{array}$ \\
\hline
\end{tabular}

Source: Adapted from Kekez, Howlett and Ramesh (2018: 246).

based on the inputs from service beneficiaries, success is highly dependent on managerial capacities (Kekez, Howlett and Ramesh 2018). In order to enable and foster such inputs, employees of organizations mandated with the co-productive service provision need to find ways to engage in the creation of knowledge and quality together with citizens and communities (Brandsen and Honingh 2016). Contracting-out, on the other hand, is about effective contracting and this requires highly skilled legal and technical analysis (Rayner, McNutt and Wellstead 2013).

Commissioning shares this need for effective analysis but is also linked to the capability of participating organizations to deliver on promises (Bovaird and Davies 2011; Taylor and Migone 2017; Kekez, Howlett and Ramesh 
2018). And the success of co-management is significantly influenced by the resources available to organizations to develop and promote partnerships between civil society, public and business organizations which can serve as smoothly functioning mechanisms for collaborative service delivery, meaning it requires essential resources for inter-organizational communication and cooperation (Agranoff 2007; Milbourne 2009; Klijn 2010; Osborne, McLaughlin and Chew 2010).

Finally, even though it features minimal government participation, certification still requires state regulatory and managerial capabilities in gaining and maintaining community acceptance of third party certifiers and in keeping certifiers honest and accountable. In this mode of collaboration, legitimacy and trust are key aspects of the certifying organizations and predictors of the success of voluntary certification arrangements (Bernstein and Cashore 2007; Kekez, Howlett and Ramesh 2018). While the assistance of skillful governmental officials and strategists is crucial for building legitimacy and authority of third party certifiers, trust between the public and certifiers and between the certifiers, certified companies and governments can be maintained only if certification standards are supported by functional accountability and adjudicative systems. Concerns about second-class regulation or corrupt standards can easily undermine years of work building up a certified brand (Zelli, Möller and van Asselt 2017).

\section{CONCLUSION AND PLAN FOR THE BOOK: THE NEED FOR MORE AND BETTER RESEARCH ON GOVERNANCE OF COLLABORATIVE SERVICE DELIVERY}

Given that all collaborative modes are vulnerable to specific kinds of failures due to these inherent vulnerabilities when governments reform or try to shift from one mode to the other modes, both practitioners and scholars need to understand not only the nature of the problem they are trying to address and the skills and resources they have at their disposal to address it, but especially the innate features of each potential service delivery mode and the capabilities and competences each requires in order to operate at a high level of performance (Howlett and Ramesh 2016; Kekez, Howlett and Ramesh 2018).

If these critical capabilities

are not taken into account or pathways through which they might distort performance of collaboration are not considered then any short-term gain enjoyed by deploying a hybrid collaborative service delivery is likely to be cancelled out later when the consequences of policy failures and poor institutional design due to its governance limitations become apparent. (Kekez, Howlett and Ramesh 2018: 248) 
To suggest a way out of this dilemma this volume not only addresses questions of when and how different collaborative arrangements might unfold, but also identifies ways in which specific government capabilities and competences can be bolstered or augmented when reforms are contemplated or implemented.

The structure of the volume reflects its aims. In order to ensure a general understanding of key concept(s), the next chapter in this introductory section of the book examines the basic concept of collaboration and how it has developed over a range of cognate discussions in the fields of public policy, public administration and governance. The chapter shows how these various discussions overlapped, but also addressed different kinds of governing challenges, and thus pointed towards different dimensions of collaboration. Rather than adjudicating a single overarching definition of collaboration, the chapter draws out the different dimensions of collaboration surfaced in these varied discussions and discusses how they relate to the differentiation between the six alternative arrangements for service delivery set out in the present chapter.

Drawing on the framework provided by introductory chapters, the second section explores in what instances consultations, contracting-out, commissioning, co-management, co-production and certification can be considered as 'collaborative' and when such service delivery arrangements are able to address specific social needs or particular sectoral problem. Chapters 3 through 8 provide a separate conceptual overview of each arrangement and discuss their critical capacities and implementation challenges. The third section and Chapters 9 through 12 address questions of how collaborative arrangements might unfold and the pitfalls they might encounter. The focus in this section is on strategic logics of influence and specific conditions for different pathways and pitfalls. The fourth, concluding, section suggests responses to implementation challenges with Chapters 13 through 15 dealing separately with ways to bolster analytical, managerial and political capacities for collaboration in public service provision.

Chapter 3, written by Genevieve Fuji Johnson and Robert Howsam, explores the potential of consultations as a form of collaboration by ranking consultative efforts on the ladder of forms and the ladder of ends. While the former ladder enables positioning of particular kinds of consultations on the continuum ranging from the disempowered to empowered (e.g. from online surveys, through advisory bodies and parliamentary committees, to participatory budgeting), the latter ladder ranks the particular ends of consultation in terms of their normative significance (e.g. from policy education, to policy stability to policy reform and on to policy justice and legitimacy). Tying forms to ends, they argue that (1) consultation is only collaborative insofar as it takes an empowered form and (2) the greater normative significance of the ends of consultation, the greater the importance of empowerment and, thus, the greater importance of collaboration. 
In Chapter 4, Maurya Dayashankar and M Ramesh investigate conditions critical for the success of contracting-out arrangements. Based on analysis of the national health insurance scheme in India, they shed light on the importance of policy-analytical capacity. To effectively contract-out delivery of public services, they argue, public managers need to be able to negotiate and govern implementation of contracts so that contracting parties have incentives for reducing costs while ensuring quality. To ensure that parties avoid perfunctory or predatory behaviour during the implementation of the contract, they furthermore argue that public managers need to be able to deploy governance measures which would address the unavoidable incompleteness of performance contracts. Their analysis shows that such measures may rely on collaboration, but when there is a conflict of interest and dependency relationship between agencies, better accountability and higher performance is achieved through the exercise of authority.

Chapter 5, by Andrea Migone, explores the opportunities that commissioning arrangements offer to public managers and tackles the specific inputs and conditions that support successful commissioning of public services. By looking at how the concept and practice of commissioning have changed the way in which public managers are approaching service delivery, he argues that the growth of commissioning is - at least in part - a response to the need for a more strategic, outcome-focused and collaborative vision in the delivery of public services. The realization of this vision requires specific support, especially with regard to outcomes-oriented approaches which can be used strategically only by governmental organizations that operate an effective information and policy analysis system. At the same time, the success of commissioning highly depends on the ability of government to mobilize stakeholders and provide them with the opportunity for meaningful interaction as well as on the analytical and managerial competencies of the commissioning team.

In a chapter devoted to co-managed service delivery arrangements, Namrata Chindarkar, Yvonne Jie Chen and Dennis Wichelns investigate the impact of contracting operations and water supply services performed by community-based civil society organizations in rural India. They show how the repair times for handpumps used by lower caste households are significantly lower in villages served through co-management arrangements than in those served by private contractors, suggesting that collaboration of the state with civil society organizations can bring about equity in access to water. While highlighting the summative importance of the efforts invested into development of analytical, managerial and political capacities of the civil society actors engaged in collaborative service provision, they argue that when properly resourced co-management can be used as an innovative and effective arrangement for providing, managing, and expanding public services. 
In Chapter 7, William Voorberg and Ingmar van Meerkerk examine co-production 'from outside-in'. They explore the boundaries of the concept by comparing literature on co-production with literature on other related concepts, such as collaborative governance; interactive governance; self-organization; co-creation and community self-organization. Based on comparison across several dimensions they argue that while the line between co-production and related concepts is very much blurred, both co-creation and community self-organization can be regarded as a specific forms of co-productive service delivery. Since the studies of all three concepts identify influential factors affecting the co-production process and since interactive and collaborative governance studies are focused on other aspects of the collaboration (e.g. relational structures and dynamics; performance; democratic anchorage), they argue, it is possible to enrich the co-production literature by applying interactive and collaborative governance perspectives.

In a chapter focused on third party certification, Joanna Vince examines the key features and conditions of collaborative efforts between third party assessment and certification organizations, other non-state actors and the state. For her, this new hybrid form of governance raises questions about accountability and responsibilities. While highlighting the centrality of the social license to operate and shareholder expectations for emerging private-social partnerships, she argues that a community's lack of trust in industry and/or certification organizations hinders the collaborative process. Based on the examination of the role of the Aquaculture Stewardship Council, a third party certifier in the Australian salmonid aquaculture industry, she sheds light on the ways in which community groups can grant or withhold a social license to operate, ceasing industry progress despite its commitments to corporate social responsibility policies and certified standards. In gaining community acceptance, she furthermore shows the capacity of third party certifiers to be accountable and the capacity of the regulatory system to ensure them legitimacy has an important role.

The section focused on the question of how collaborative service delivery may unfold is opened by Chapter 9 in which Ingmar van Meerkerk reflects on the different pathways to collaboration between citizens and governments. Based on literature on citizen participation, co-production and community-based initiatives, he highlights the distinction between bottom-up pathways initiated and for an important part led by groups of citizens and top-down pathways initiated and led by government institutions. In the growing literature on collaborative service delivery, he argues, it is important to take notice of different pathways as they are characterized by different dynamics leading to specific challenges in implementation and assessment. By looking at why (motives), how (crucial capacities) and who (representative- 
ness) questions of bottom-up and top-down collaboration, he illuminates key participation traps aligned with each of the two pathways.

In a chapter devoted to bottom-up logics of influence, Benjamin Cashore analyses evolutionary pathways of certification systems and capacity challenges government officials are facing when trying to foster collaborative processes in this type of non-state market-driven governance institution. While focusing attention on individual policy capacity requirements, he offers a hierarchical pecking order. Political and analytical capabilities, he argues, must be first exercised, as they are key for identifying and travelling one among four potential pathways through which certification systems emerge and have influence: direct pathway (by gaining authority to create policy to which most businesses adhere), superseding pathway (governments adopting private standards as a part of a policy learning), symbiotic pathway (by filling gaps in public policies), and hybrid pathway (by reinforcing government policies, rather than private standards). Managerial competencies, he furthermore argues, must be applied subsequently as they will vary somewhat depending upon which pathway is chosen.

In a chapter devoted to top-down pathways, Tony Bovaird and Elke Loeffler explore the recent history of the commissioning approach to public services and the different strategic directions in which this collaborative arrangement might unfold and make an impact. By looking at ways in which the collaboration between public service commissioners and providers can be organized, they distinguish four strategic directions ranging from one-to-one commissioner-provider relationships, via single commissioner outsourcing to a partnership of providers towards joint commissioning of a single provider and, finally, on to joint commissioning of a partnership of providers. While conceiving these four strategic directions as key pathways to public value creation, they argue that in order to be successful, commissioned service delivery needs to mobilize all local resources of citizens and communities, not just public sector resources, in the co-commissioning, co-design, co-delivery and co-assessment of public services.

Pathways through which collaborative implementation arrangements might be used not just for tackling collective problems but also for the advancing of particularistic political objectives are then explored in Chapter 12 by Anka Kekez and Andrija Henjak. By focusing on the metagoverning process through which collaboration-inspired reformist ideas are turned into service delivery practice, they highlight the role executive politicians have in ensuring democratically anchored and effective public services. However, they argue, if performed by elected officials who are incentivized to engage politicized allocation of public goods and jobs in systems of government where they are not held accountable to citizens for the quality and quantity of services provided, the metagovernance role can be misused. Based on the analysis of reform of 
elderly care services in Croatia, they show how the metagovernance process was used by patronage-driven politicians as a route to turn collaborative service provision into opportunities to use state resources for accommodating rent-seeking needs.

The fourth, concluding section, is opened by Chapter 13 in which Michael Mintrom and Madeline Thomas look at the ways in which design thinking can be used to augment the analytical capabilities of governing actors in the realm of commissioning arrangements. To show how commissioning could lead towards more innovation and improved returns on the investment of public funds, they explore techniques used for tapping the knowledge of targeted individuals, creating opportunities for significant public engagement of diverse perspectives, and prototyping interventions. Drawing insights from the illustrative case of Uncommon Schools, a non-profit network of public charter schools operating in the United States, they argue that harnessing the knowledge of local context through improved client engagement and design thinking approaches can improve collaborative efforts in service delivery and increase the odds that public investments will generate anticipated social and economic outcomes.

Managerial capabilities of governing actors are then addressed in Chapter 14 in which Isha Dayal utilizes the lens of 'governance modes' to investigate the relationship between public sector reforms and the contractual relations shared between the principal and agent in public service delivery. By undertaking a thorough review of the literature, she shows how contractual relations tend to be managed differently in different governance modes and in - with those modes aligned - arrangements for public service delivery. While the move from a 'hierarchical' towards a 'market' orientation of public service delivery has induced the shift from behaviour-based to outcome-based contracts, she argues, it did not imply the separation of contractual relations from the theories of principal-agent and agency. If managerial capacities of governing actors in collaborative arrangements are to be enhanced, she furthermore argues, contractual relations between actors involved in service provision need to be separated from principal-agent theory and move towards more collaborative contractual frameworks.

Finally, the political capabilities of governing actors are tackled in Chapter 15 in which Lihi Lahat and Neta Sher-Hadar explore ways to strengthen judgments about when is it beneficial to embrace collaborative service delivery and when it is not. Capabilities of policymakers to make such judgments, they argue, can be bolstered with better understanding of the conditions that encourage the implementation of collaborative arrangements in different types of decision-making situations. Based on Thompson and Tuden's (1959) typology of decision-making strategies in organizations, which vary in their extent of agreement or disagreement about fact and value elements, they suggest there 
are different situations, some of which are more beneficial than others. Their concluding argument is that collaborative governance is worthwhile when there is some disagreement about either the value elements or factual elements of a policy, but not in cases where there is full agreement about both of these elements. 